${ }^{2}$ Ambrosioni E, Tartagni F, Montebugnoli L, Magnani B. Intralymphocytic sodium in hypertensive patients: a significant correlation. Clin Sci 1979;57, suppl:325-7s.

${ }^{3}$ Poston L, Sewell RB, Wilkinson SP, et al. Evidence for a circulating sodium transport inhibitor in essential hypertension. $\mathrm{Br}$ Med $\mathcal{F} 1981$; 282:847-9.

${ }^{4}$ Heagerty AM, Milner M, Bing RF, Thurston H, Swales JD. Leucocyte membrane sodium transport in normotensive populations: dissociation of abnormalities of sodium efflux from raised blood pressure. Lancet 1982; ii :894-6.

${ }^{5}$ Blaustein MP. Sodium ions, calcium ions, blood pressure regulation, and hypertension: a reassessment and a hypothesis. Am f Physiol 1977; 232:C165-73.

${ }^{6}$ Hilton PJ, Patrick J. Sodium and potassium flux rates in normal human leucocytes in an artificial extracellular fluid. Clin $S_{c i} 1973 ; 44: 439-45$.
' Lowry OH, Rosebrough NJ, Farr AC, Randall RJ. Protein measurement with the Folin phenol reagent. $\mathcal{F}$ Biol Chem 1951;193:265-75.

${ }^{8}$ Glitsch HG, Reuter H, Scholz $H$. The effect of the internal sodium concentration on calcium fluxes in isolated guinea pig auricles. $\mathcal{f}$ Physiol (Lond) 1970;209:25-43.

${ }^{9}$ Romero PJ, Whittam R. The control by internal calcium of membrane permeability to sodium and potassium. F Physiol (Lond) $1971 ; 214$ : 481-507.

${ }^{10}$ Glynn JM, Karlish SJD. The sodium pump. Annu Rev Physiol 1975; 37:13-55.

11 Poston L, Jones RB, Richardson PJ, Hilton PJ. The effect of antihypertensive therapy on abnormal leucocyte sodium transport in essential hypertension. Clin Exp Hypertens 1981 ;3:693-701.

(Accepted 12 December 1983)

\title{
Malabsorption of protein bound vitamin $B_{12}$
}

\author{
D W DAWSON, A H SAWERS, R K SHARMA
}

\begin{abstract}
Patients with subnormal serum vitamin $B_{12}$ concentrations were tested for absorption of protein bound vitamin $B_{12}$ and compared with controls. Absorption of the protein bound vitamin appeared to decrease with increasing age in healthy subjects. Differences between the result of this test and the result of the Schilling test in patients who had undergone gastric surgery were confirmed; such differences were also seen in some patients who had iron deficiency anaemia, an excessive alcohol intake, or folate deficiency. Defective absorption was also found in six patients with an adequate dietary intake of vitamin $B_{12}$, normal Schilling test results, low serum vitamin concentrations, and tissue changes responding to treatment with vitamin $B_{12}$.

Malabsorption of the vitamin from protein bound sources, which is not detected by the Schilling test, may produce vitamin $B_{12}$ deficiency of clinical importance.
\end{abstract}

\section{Introduction}

One of the standard procedures used to investigate a low serum concentration of vitamin $B_{12}$ (cobalamin) is the Schilling test. Introduced in 1953, this measures ability to absorb cobalamin from an aqueous solution. ${ }^{1}$ In more recent years, however, it has been suggested that in certain cases there is a lack of correlation between the results of the Schilling test and the cobalamin state of the patient. For example, after partial gastrectomy true tissue cobalamin deficiency may develop despite a normal Schilling test result. ${ }^{2}$ In such instances it has been proposed that there is malabsorption of the vitamin that is not shown by the test. To show this malabsorption several tests of absorption of protein bound cobalamin (which are claimed to approximate more closely to the physiological process) have been used in small numbers of patients. ${ }^{3}{ }^{4}$ In one such test the vitamin is bound to chicken serum.

The aim of the present study was to assess the absorption of

North Manchester General Hospital, Manchester M8 6RH

D W DAWSON, FRCP, FRCPATH, consultant haematologist

A H SAWERS, MRCP, MRCPATH, senior registrar in haematology

R K SHARMA, MB, MRCP, senior registrar in geriatrics

Correspondence to: Dr D W Dawson. protein bound cobalamin in patients with low serum cobalamin concentrations. The test was performed on a control group of volunteers and on patients suffering from a variety of conditions. All but three patients had low serum concentrations of cobala$\min$.

\section{Methods and subjects \\ LABORATORY TECHNIQUES}

Blood counts were done with a Coulter S-Plus. Serum cobalamin concentrations were determined by radioisotope assay with the technique of saturation analysis; pure human intrinsic factor served as the binder (reference range 170-900 ng/l). This method has been used for 10 years in the haematology department of this hospital and has been validated by comparison with euglena assay. With this assay nearly all patients with pernicious anaemia show serum concentrations below $50 \mathrm{ng} / \mathrm{l}$. Serum and erythrocyte folate concentrations were measured microbiologically with Lactobacillus casei (reference ranges: serum folate 3-12 $\mu \mathrm{g} / \mathrm{l}$, erythrocyte folate $160-600 \mu \mathrm{g} / \mathrm{l})$. In selected patients gastric juice collected over one hour was analysed for acid and intrinsic factor after stimulation with pentagastrin. Serum gastrin concentrations were assayed with the radioimmunoassay Gastrin-17 kit (reference range $50-250 \mathrm{ng} / \mathrm{l}$ ) as an indirect measurement of gastric acidity.

The test of absorption of protein bound cobalamin was done with cyanocobalamin, labelled with cobalt-57, bound to chicken serum (Tissue Culture Services, Slough). Individual doses were prepared by mixing $4 \mathrm{ml}$ sterile chicken serum with the standard Schilling test dose of $1 \mu \mathrm{g}(0.037 \mathrm{MBq} ; 1 \mu \mathrm{ci})$ cobalamin in aqueous solution $(30 \mathrm{ml})$. Total and rapid binding of the vitamin was shown in sample doses by the addition of albumin coated charcoal and centrifugation; there was no loss of isotope counts from the supernatant. The chicken serum itself contained only a very small amount of cobalamin. The oral dose of protein bound vitamin was given together with an intramuscular injection of $1 \mathrm{mg}$ unlabelled cobalamin, and urinary excretion of the labelled vitamin was measured over the next 24 hours. The isotope excreted in $4 \mathrm{ml}$ aliquots of urine was counted for 100 minutes in a Beckman Biogamma counter. The $95 \%$ confidence limits at an excretion level of $0.3 \%$ were $\pm 0.044 \%$.

Schilling tests were also performed. Urinary excretion of the isotope over 24 hours (normal $10 \%$ or more) was measured. The $95 \%$ confidence limits at an excretion level of $10 \%$ were $\pm 1 \cdot 2 \%$.

\section{SUBJECTS}

We studied 49 subjects. Fifteen served as controls, and the remainder comprised six patients with pernicious anaemia, six who had undergone gastrectomy, four with chronic iron deficiency anaemia, eight with folate deficiency, four alcohol abusers, and six others. 
Controls-The 15 controls were aged from 24 to 87 and were arbitrarily split into those aged under 60 (seven subjects) and those aged 60 or more (eight). The seven younger subjects were all men and members of the hospital staff; the older subjects, four men and four women, were patients in a long stay geriatric unit. Each had a normal blood count, a normal serum cobalamin concentration (mean 300 (range 180-400) ng/l), normal folate concentrations, and no evidence of renal dysfunction.

Patients with pernicious anaemia-All six patients had a low serum cobalamin concentration (mean 40 (range 30-50) ng/l), megaloblastic anaemia responsive to cobalamin, achlorhydria, low gastric output of intrinsic factor, and subnormal responses to Schilling tests, which were corrected by administration of intrinsic factor.

Patients after partial gastrectomy-Six of the patients studied had undergone partial gastrectomy several years previously. Four had low serum cobalamin concentrations (range 40-150 ng/l), one of whom also

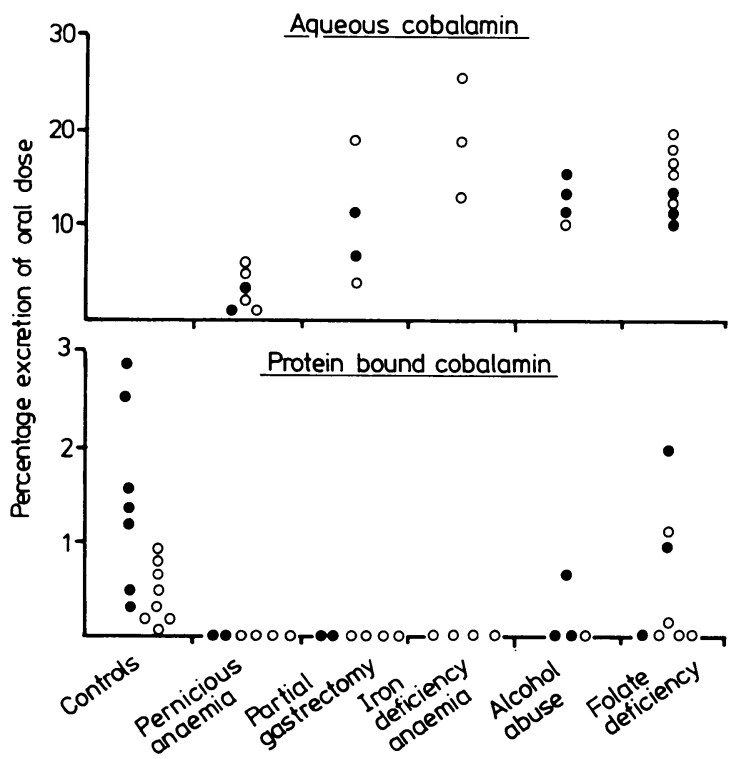

Results of Schilling tests (top) and protein bound cobalamin absorption tests in controls and patients. $=$ Subject aged under 60 . $\bigcirc=$ Subject aged 60 or over.

had megaloblastic anaemia; one had a normal serum concentration $(225 \mathrm{ng} / \mathrm{l})$; and one was receiving treatment with cobalamin when first seen. Three of them were aged under 60 .

Patients with chronic iron deficiency anaemia-These four patients were all aged over 60 and had low serum cobalamin concentrations (mean 90 (range 65-100) $\mathrm{ng} / \mathrm{l}$ ). Three were tested for absorption of protein bound cobalamin while iron deficient and one after iron treatment. There was no evidence of tissue cobalamin deficiency at presentation.

Alcohol abusers-These four patients were all aged under 60. One had a normal and three a subnormal (range 40-130 ng/1; cobalamin concentration. None was folate deficient or had evidence of tissue cobalamin deficiency.

Patients with folate deficiency-Three of these eight patients were aged under 60 . All had subnormal serum cobalamin concentrations (mean 105 (range 65-165) $\mathrm{ng} / \mathrm{l}$ ). In one patient folate deficiency was secondary to gluten enteropathy, and in the others it was dietary in origin. In four there was an additional factor of excess alcohol intake.

Other patients - Six other patients were studied who, though having low serum cobalamin concentrations, did not fall into any of the previous categories. All had macrocytosis on presentation.

\section{Results}

The figure shows the results of the absorption tests in all patients and controls.

Controls-The mean excretion of isotope was 0.93 (SEM 0.22 ) $\%$. In the younger age group it was $1.43(0.36) \%$ and in the older age group $0.5(0 \cdot 12) \%$. Although the difference between these two values did not reach significance, the results suggest a lower excretion in older subjects. We interpreted an excretion of less than $0.3 \%$ as abnormal in subjects under 60 years of age and accepted only zero excretion as being definitely abnormal in older subjects. There was no apparent difference in results between the elderly men and elderly women. Serum gastrin concentrations were normal (mean $115 \mathrm{ng} / \mathrm{l}$ ).

Patients with pernicious anaemia-There was no detectable excretion of isotope in any of the patients on testing for absorption of protein bound cobalamin. Excretion in the Schilling tests ranged from 0.2 to $5.0 \%$. The mean serum gastrin concentration was $838 \mathrm{ng} / \mathrm{l}$, with one normal result.

Patients with partial gastrectomy-None excreted any of the protein bound vitamin. The Schilling test yielded normal results in two of these patients (one of whom had presented with megaloblastic anaemia) and subnormal results in two.

Patients with chronic iron deficiency anaemia-None of the patients excreted any of the protein bound vitamin. The Schilling test yielded normal results in three patients and was not done in the other patient. The mean serum gastrin concentration was $180 \mathrm{ng} / \mathrm{l}$, with one result above normal.

Alcchol abusers-One patient yielded a normal result to the protein bound cobalamin absorption test; his serum cobalamin concentration was normal. All four patients yielded normal results to Schilling tests.

Patients with folate deficiency-Four patients, two with excessive alcohol intake, did not excrete any of the protein bound vitamin and showed no rise in serum cobalamin concentrations when treated with folic acid. Four (including the patient with gluten enteropathy) yielded results to protein bound cobalamin absorption tests that were within our normal ranges for the appropriate age: two of these were given folic acid, and their serum cobalamin concentration reverted to normal; one patient who abused alcohol, refused to take folic acid; and the remaining patient, who also abused alcohol, showed no change in his serum cobalamin concentration when treated with folic acid. Schilling tests yielded normal results in all eight patients.

Other patients-The table shows the haematological data and results of the absorption tests in these six patients. Serum cobalamin concentrations were all subnormal. After treatment with hydroxocobalamin $1 \mathrm{mg}$ administered intramuscularly at the same time as the Schilling test hypersegmented neutrophils disappeared from the blood in all patients; marrow examinations were not repeated. Three patients showed zero and three reduced excretion in the protein bound cobalamin absorption tests. The Schilling tests yielded normal results. More detailed case reports of these six patients are given below.

\section{Case reports}

Case 1-A routine check two years after treatment for iron deficiency anaemia showed macrocytosis. The patient had been treated for thyrotoxicosis 30 years previously. A repeat Schilling test 14 months after the first showed reduced absorption at $6 \%$.

Case 2-The patient presented with autoimmune haemolytic anaemia due to methyldopa. On examination his haemoglobin concentration was $7 \cdot 9 \mathrm{~g} / \mathrm{dl}$, mean cell volume $114 \mathrm{fl}$, serum cobalamin concentration $225 \mathrm{ng} / \mathrm{l}$, and serum folate concentration $9.5 \mu \mathrm{g} / \mathrm{l}$. Eighteen months later macrocytosis recurred. The serum cobalamin concentration was then $145 \mathrm{ng} / \mathrm{l}$ and, three months later, $105 \mathrm{ng} / \mathrm{l}$.

Case 3-Macrocytic anaemia was noted after a chest infection treated with co-trimoxazole. The patient complained of paraesthesia in his feet, and impairment of sensation, position sense, and vibration sense were found in his lower legs. He did not drink alcohol or smoke. He had a hiatus hernia, which had been repaired twice, with occult blood loss. The paraesthesia resolved after treatment with cobalamin.

Case 4-The patient presented with chest pains. Investigations showed a carcinoma of the stomach. His mean cell volume fell to $98 \mathrm{fl}$ in the two months before operation. The tumour occupied $9 \mathrm{~cm}$ of the body of the stomach, and mild atrophic gastritis was found to be affecting the fundus and antrum. He died of postoperative complications.

Case 5-The patient presented with megaloblastic anaemia, haemoglobin concentration $9.2 \mathrm{~g} / \mathrm{dl}$, and mean cell volume $100 \mathrm{fl}$ and had a history of iron deficiency anaemia. Marrow iron stores were absent, and on treatment with iron her blood count rose (see table), at which time the absorption tests were done.

Case 6-The patient presented with myositis of both gastrocnemii, which eventually resolved after treatment with steroids. Faecal fats, xylose excretion, and urinary indican concentration were normal. Barium studies showed a few ileal diverticulums. Results of the protein bound cobalamin absorption test did not improve after five days' treatment with oxytetracycline. 
Haematological data and results of absorption tests in six patients with macrocytosis and cobalamin deficiency

\begin{tabular}{|c|c|c|c|c|c|c|c|c|c|c|c|c|c|c|c|c|c|}
\hline \multirow{2}{*}{ Case No } & \multirow{2}{*}{$\underset{\text { (years) }}{\text { Age }}$} & \multirow{2}{*}{$\begin{array}{c}\text { Haemoglobin } \\
(\mathbf{g} / \mathrm{d} \mathbf{d})\end{array}$} & \multirow{2}{*}{$\begin{array}{c}\text { Mean cell } \\
\text { volume } \\
(\mu)\end{array}$} & \multirow{2}{*}{$\underset{\substack{\text { Serum } \\
\text { cobalamin }}}{\text { Serl }}$} & \multirow{2}{*}{$\begin{array}{c}\text { Serum } \\
\text { folate } \\
(\mu \mathbf{g} / 1)\end{array}$} & \multirow{2}{*}{$\begin{array}{l}\text { Erythrocyte } \\
\text { folate } \\
(\mu \mathbf{g} / 1)\end{array}$} & \multicolumn{2}{|c|}{ Antibodies in blood } & \multirow{2}{*}{ Marrow } & \multicolumn{3}{|c|}{ Gastric juice } & \multirow{2}{*}{ 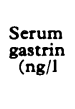 } & \multicolumn{2}{|c|}{$\begin{array}{l}\% \text { isotope excreted in } \\
\text { absorption tests }\end{array}$} & \multicolumn{2}{|c|}{$\begin{array}{c}\text { Response to } \\
\text { cobalamin treatment } \dagger\end{array}$} \\
\hline & & & & & & & $\begin{array}{c}\text { Parietal } \\
\text { cell }\end{array}$ & $\frac{\text { Intrinsic }}{\text { factor }}$ & & $\mathrm{pH}$ & $\frac{\text { Intri }}{\mathrm{U} / \mathrm{ml}}$ & $\frac{\text { ssic factor }}{\text { Total units }}$ & & Schilling & $\begin{array}{c}\text { Protein bound } \\
\text { cobalamin }\end{array}$ & $\begin{array}{c}\text { Haemoglobin } \\
(\mathbf{g} / \mathrm{d} d)\end{array}$ & $\begin{array}{l}\text { Mean cell } \\
\text { volumet } \\
\text { (fi) }\end{array}$ \\
\hline $\begin{array}{l}1 \\
2 \\
3 \\
4 \\
5 \\
6\end{array}$ & $\begin{array}{l}69 \\
65 \\
75 \\
53 \\
37 \\
29\end{array}$ & $\begin{array}{l}12.4 \\
12.4 \\
11.9 \\
16.4 \\
10.9 \\
12.8\end{array}$ & $\begin{array}{l}112 \\
102 \\
104 \\
105 \\
108 \\
120\end{array}$ & $\begin{array}{r}110 \\
125 \\
150 \\
110 \\
115 \\
60\end{array}$ & $\begin{array}{l}5.8 \\
9.5 \\
4.4 \\
4.0 \\
3.0 \\
3.0\end{array}$ & $\begin{array}{l}125 \\
370 \\
185 \\
220 \\
145\end{array}$ & $\begin{array}{l}\overline{+} \\
\pm \\
\pm \\
\pm\end{array}$ & $\begin{array}{l}\bar{z} \\
\overline{-} \\
z \\
-\end{array}$ & $\begin{array}{l}\mathrm{HN} \\
\mathrm{HN} \\
\mathrm{M} \\
\mathrm{M} \\
\mathrm{M} \\
\mathrm{M}\end{array}$ & $\begin{array}{l}6.7 \\
8.3 \\
5.8\end{array}$ & $\begin{array}{r}5 \\
19 \\
4\end{array}$ & $\begin{array}{r}90 \\
570 \\
100\end{array}$ & $\begin{array}{r}88 \\
313 \\
163 \\
470 \\
88 \\
106\end{array}$ & $\begin{array}{l}12 \\
13 \\
228 \\
218 \\
21 \\
17\end{array}$ & $\begin{array}{l}0 \\
0 \\
0 \\
0 \cdot 2 \\
0 \cdot 2 \\
0.1\end{array}$ & $\begin{array}{l}14.2 \\
12.0 \\
12.4 \\
15.7 \\
15.3 \\
15.2\end{array}$ & $\begin{array}{l}90 \\
96 \\
89 \\
98 \\
90 \\
96\end{array}$ \\
\hline
\end{tabular}

$\mathrm{HN}=$ Increased percentage of hypersegmented neutrophils in blood film. $M=$ Megaloblastic marrow.

- Mean of two or more estimations made at an interval of at least four weeks.
+ Values given are those reached three or more months after treatment, except in case 4.

I Lowest of a series of decreasing values.
8 Eight hour plasma isotope uptake also normal; not estimated in other patients.

\section{Patients with low serum cobalamin concentrations}

In total 29 patients with low serum cobalamin concentrations underwent both Schilling and protein bound cobalamin absorption tests. Eight patients $(28 \%$ ) yielded abnormal results to the Schilling test and 22 patients $(76 \%$ ) abnormal results to the protein bound cobalamin absorption test; 14 patients yielded normal results to Schilling tests but did not excrete any isotope in the protein bound cobalamin absorption test. This last group consisted of one patient who had undergone partial gastrectomy, three patients with iron deficiency, two with folate deficiency and alcohol abuse, and three of those listed in the table (cases 1, 2, and 3).

\section{Discussion}

Dietary cobalamin is bound to protein. The normal process of absorption of the vitamin requires its removal from food protein before its eventual binding by intrinsic factor. This process is thought to require the presence of gastric acid and pepsin. If there is adequate secretion of intrinsic factor tests of absorption of unbound vitamin may fail to reflect gastric dysfunction associated with defective removal of the vitamin from dietary protein.

The absorption of radiolabelled cobalamin from dietary sources has been investigated with mutton, ${ }^{5}$ raw and cooked eggs, ${ }^{3}$ and chicken meat. ${ }^{6}$ Two tests of absorption of protein bound vitamin have been studied in particular; in these cobalt-57 cyanocobalamin was added in vitro to ovalbumin ${ }^{3}$ and chicken serum. ${ }^{4}$ Such tests have been applied to patients with known defects of gastric function including pernicious anaemia, atrophic gastritis, and postgastrectomy states ${ }^{3}$ and during treatment with cimetidine. ${ }^{7}$ Defects in absorption of protein bound vitamin have been shown in such cases. This defect can be improved by the administration of hydrochloric acid, pepsin, and intrinsic factor, or a combination thereof. ${ }^{8}$

In the present study we used a test of absorption of protein bound cobalamin to investigate patients presenting with low serum concentrations of cobalamin. In this test we used cobalt-57 cyanocobalamin bound to chicken serum; we chose this particular form of protein binder because of the ease of preparation of the test doses. We do not claim that the absorption of vitamin bound to chicken serum exactly reproduces the absorption of the vitamin from a varied diet. Nevertheless, results from tests using chicken serum correlate with those from tests using foods such as eggs and chicken meat.

When establishing our reference range for the test we found that there was a trend towards lower values with increasing age. This presumably reflects the increasing incidence of gastritis and hypochlorhydria in elderly people. ${ }^{9}$ There is some debate over whether mean serum cobalamin concentrations are lower in elderly than in young people. Absorption of aqueous cobalamin is not affected by age. ${ }^{10} \mathrm{~A}$ recent study, however, showed appreciably lower cobalamin concentrations in elderly subjects when an assay system with a specific binder was used. ${ }^{11}$ Further work has indicated a closer correlation of serum cobalamin concentration with maximal gastric acid output than with secretion of intrinsic factor. ${ }^{12}$ Our results indicated that we had to take age into consideration when interpreting excretion in the protein bound cobalamin absorption test. We therefore took only zero excretion as being definitely abnormal, although results of less than $0.3 \%$ probably represent defective absorption in younger subjects.

Defective absorption of protein bound cobalamin was found in all patients with pernicious anaemia and all those who had undergone partial gastrectomy, in whom the result of the test is presumably influenced by the ability of the stomach remnant to secrete sufficient acid and pepsin, and this will vary from patient to patient. We would therefore expect to obtain normal results to tests of protein bound cobalamin absorption in many patients who have undergone partial gastrectomy and have normal cobalamin concentrations, but this remains to be confirmed. Chronic iron deficiency is associated with reduced secretion of gastric acid, and this is presumably reflected by the abnormal results yielded to protein bound cobalamin absorption tests in this group. One patient, in whom the Schilling test gave a normal result but in whom absorption of protein bound cobalamin was abnormal, still showed normal absorption of aqueous cobalamin 18 months later, at which time circulating intrinsic factor antibodies had appeared and gastric analysis showed achlorhydria with adequate secretion of intrinsic factor. More recently we tested two other patients with chronic iron deficiency anaemia and normal serum cobalamin concentrations; absorption of protein bound cobalamin was normal in both.

A low serum cobalamin concentration in the absence of folate deficiency is not generally considered to be a feature of excessive alcohol intake, but occasional cases have been described. ${ }^{13}$ Reduced absorption of aqueous cobalamin after alcohol ingestion has been attributed to ileal damage. ${ }^{14}$ The abnormal results of protein bound cobalamin absorption tests, normal results of Schilling tests, and low serum cobalamin concentrations in our small group suggest that another, presumably gastric, factor may be important. None of the patients had evidence of pancreatitis.

No constant pattern of absorption of protein bound vitamin was found in the patients with folate deficiency. The relation of the result of the protein bound cobalamin absorption test to the change in the serum cobalamin concentration with folic acid treatment suggests that a (coincidental) gastric lesion should be considered in the investigation of a persistently low serum cobalamin concentration in nutritional folate deficiency.

Of the 14 patients who yielded normal results to the Schilling test but did not excrete any isotope in the protein bound cobalamin absorption test, six (one with iron deficiency, two with folate deficiency, and three of those listed in the table) consented to undergo gastric analysis. They were found to have reduced secretion of gastric acid after stimulation with pentagastrin. Two others were considered to have reduced secretion of gastric acid on the basis of raised serum gastrin concentrations. The remainder had normal gastrin concentrations, and no firm conclusion concerning gastrin function could be drawn. Normal serum gastrin concentrations may occur in achlorhydria when gastritis affects the antrum as well as the fundus of the stomach. ${ }^{15}$

Patients with atrophic gastritis often have a low serum cobalamin concentration, though they only occasionally develop pernicious anaemia. The normal results of the Schilling test in the six "other patients" reported on here exclude this disease by current standards of interpretation and definition. The Schilling test, however, only assesses secretion of intrinsic factor whereas 
the protein bound cobalamin absorption test takes into account the release of cobalamin from protein as well. By doing so it probably shows an earlier and lesser degree of gastric atrophy than that found in pernicious anaemia that is nevertheless sufficient to lead to cobalamin deficiency. Excluding patients who have undergone gastric surgery, we have found only two other case reports of malabsorption of cobalamin with megaloblastic anaemia and normal Schilling test results. ${ }^{16} 17$

There is a tendency to dismiss a low serum cobalamin concentration as being of no clinical importance if results of a Schilling test are normal and the patient is not a vegan. Our findings suggest that persistently subnormal results of serum cobalamin assays should not be readily discounted as the product of an error of technique ${ }^{18}$ : the investigation of patients with cobalamin deficiency and normal results to the Schilling test should include a test of absorption of protein bound cobalamin.

We thank our consultant colleagues for referring many of the patients, Mr D I Fish for technical help, and Professor S R Bloom for advice on gastrin assays.

\section{References}

${ }^{1}$ Schilling RF. Intrinsic factor studies. II. The effect of gastric juice on the urinary excretion of radioactivity after the oral administration of radioactive vitamin B B $_{12}$ f Lab Clin Med 1953;42:860-6.

${ }^{2}$ Mahmud K, Ripley D, Doscherholmen A. Vitamin $B_{12}$ absorption tests. Their unreliability in postgastrectomy states. $\mathcal{F} A M A 1971 ; 216: 1167-71$.

${ }^{3}$ Doscherholmen A, McMahon J, Ripley D. Inhibitory effect of eggs on vitamin $B_{12}$ absorption: description of a simple ovalbumin ${ }^{57} \mathrm{Co}$-vitamin $B_{12}$ absorption test. $B r \mathcal{F}$ Haematol 1976;33:261-72.

4 Streeter AM, Balasubramaniam D, Boyle R, O’Neill BJ, Pheils MT. Malabsorption of vitamin $B_{12}$ after vagotomy. Am $\mathcal{f}$ Surg 1974;128: 340-3.
${ }^{5}$ Heyssel RM, Bozian RC, Darby WJ, Bell MC. Vitamin B $_{12}$ turnover in man. The assimilation of vitamin $B_{12}$ from natural foodstuff by man and estimates of minimal daily dietary requirements. Am f Clin Nutr 1966; 18:176-84.

${ }^{6}$ Doscherholmen A, McMahon J, Ripley D. Vitamin $B_{12}$ assimilation from chicken meat. Am f Clin Nutr 1978;31:825-30.

' Steinberg WM, King CE, Toskes PP. Malabsorption of protein-bound cobalamin but not unbound cobalamin during cimetidine administration. Dig Dis Sci 1980;25:188-92.

${ }^{8}$ King CE, Leibach J, Toskes PP. Clinically significant vitamin $\mathbf{B}_{12}$ deficiency secondary to malabsorption of protein-bound vitamin $\mathbf{B}_{12}$. Dig Dis Sci 1979;24:397-402.

Chanarin I. The megaloblastic anaemias. 2nd ed. Oxford: Blackwell Scientific. 1979:378.

${ }^{10}$ McEvoy AW, Fenwick JD, Boddy K, James OFW. Vitamin B 12 absorption from the gut does not decline with age in normal elderly humans. Age Ageing 1982;11:180-3.

${ }^{11}$ Magnus EM, Bache-Wiig JE, Aanderson TR, Melbostad E. Folate and vitamin $B_{12}$ (cobalamin) blood levels in elderly persons in geriatric homes. Scand f Haematol 1982;28:360-6.

${ }^{12}$ Doscherholmen A, Ripley D, Chang S, Silvis SE. Influence of age and stomach function on serum vitamin $B_{12}$ concentration. Scand $\mathcal{F}$ Gastroenterol 1977; 12:313-9.

${ }^{13}$ Wickramasinghe SN. Review. The deoxyuridine suppression test : a review of its clinical and research applications. Clin Lab Haematol 1981;3:1-18.

${ }^{14}$ Lindenbaum J, Leiber CS. Alcohol-induced malabsorption of vitamin $B_{12}$ in man. Nature $1969 ; 224: 806$

${ }^{15}$ Lewin KJ, Dowling F, Wright JP, Taylor KB. Gastric morphology and serum gastrin levels in pernicious anaemia. Gut 1976;17:551-60.

${ }^{16}$ Carmel R. Nutritional vitamin $B_{12}$ deficiency. Possible contributory role of subtle vitamin $\mathrm{B}_{12}$ malabsorption. Ann Intern Med 1978;88:647-9.

17 Streeter AM, Shum H-Y, Duncombe VM, Hewson JW, Thorpe MEC. Vitamin $B_{12}$ malabsorption associated with a normal Schilling test result. Med F Aust 1976;1:54-5.

${ }^{18}$ Brynskov J, Andersen K, Gimsing P, Hippe F. False low serum vitamin $B_{12}$ values with radiodilution assays using blocked $R$-binders. Lancet $1983 ; \mathrm{i}: 1104-5$.

(Accepted 9 December 1983)

\title{
Relation between osmolality of diet and gastrointestinal side effects in enteral nutrition
}

\author{
P P KEOHANE, HELEN ATTRILL, MARY LOVE, P FROST, D B A SILK
}

\begin{abstract}
One hundred and eighteen patients with normal gastrointestinal function were randomly allocated to one of three feeding regimens in a double blind study to determine the relation between the tonicity of the diet and gastrointestinal side effects related to the diet and to evaluate the efficacy of "starter" regimens in reducing gastrointestinal side effects during enteral nutrition. Patients received a hypertonic diet with an osmolality of $430 \mathrm{mmol}$ (mosmol)/kg (group 1), the same diet but with the osmolality increasing from 145 to $430 \mathrm{mmol} / \mathrm{kg}$ over the first four days (group 2), or an isotonic diet (300 mmol/kg) (group 3). All diets were prepared aseptic-
\end{abstract}

\footnotetext{
Departments of Gastroenterology and Clinical Nutrition and Chemical Pathology, Central Middlesex Hospital, London NW10 P P KEOHANE, MRCP, Medical Research Council research fellow HELEN ATTRILL, SRN, nutrition nurse MARY LOVE, SRD, dietitian

P FROST, MRCPATH, consultant chemical pathologist

D B A SILK, FRCP, consultant physician
}

Correspondence to: Dr P P Keohane, Erl Wood Manor, Windlesham, Surrey GU20 6PH ally and administered by 24 hour nasogastric infusion. The mean daily nitrogen intake in group 1 was significantly greater $(p<0.05)$ than that in both groups 2 and 3 , and the mean overall daily nitrogen balance was significantly better $(p<0.05)$ in group 1 than groups 2 and 3. The incidence of side effects related to the diet was similar in all three groups, but diarrhoea was significantly $(p<0.001)$ associated with concurrent treatment with antibiotics.

These findings show that undiluted hypertonic diet results in significantly better nitrogen intake and balance, that starter regimens reduce nutrient intake but not symptoms, and that diarrhoea is significantly related to treatment with antibiotics and not to administration of an undiluted hypertonic polymeric diet.

\section{Introduction}

Enteral feeding is widely used to provide nutritional support, and proprietary whole protein polymeric diets are recommended for patients with normal gastrointestinal function. The effectiveness of this technique, however, may be limited by gastrointestinal side effects related to diet, particularly diarrhoea, which develop in up to $25 \%$ of patients. ${ }^{12}$ 